\title{
Pengaruh Keaktifan dalam Organisasi terhadap Motivasi Belajar Matematika Siswa SMA Negeri 1 Campalagian
}

\author{
Nasaruddin ${ }^{*}$, Rezki Amaliyah $\mathrm{AR}^{2}$ \\ ${ }^{1,2}$ Universitas Sulawesi Barat \\ 1'nasaruddin.nasar@gmail.com. ${ }^{2}$ rezkiamaliyah.ar@unsulbar.ac.id
}

\begin{abstract}
Abstrak
Penelitian ini merupakan jenis penelitian expost facto dengan pendekatan kuantitatif yang bertujuan untuk mengetahui pengaruh keaktifan dalam ornagisasi terhadap motivasi belajar matematika siswa SMA Negeri 1 Campalagian. Penelitian ini dilakukan di SMA Negeri 1 Campalagian dengan subjek penelitian siswa yang masuk dalam pengurus OSIS tahun ajaran 2016/2017 yang berjumlah 29 responden. Penelitian ini menggunakan dua variabel yaitu: variabel bebas : 1). keaktifan dalam organisasi $(X)$, 2). variabel terikat: motivasi belajar matematika (Y). Teknik pengumpulan data dalam penelitian ini menggunakan angket yang terdiri atas instrumen penelitian keaktifan dalam organisasi dan motivasi belajar matematika dengan skala Likert. Keabsahan data diperoleh melalui uji validitas dan riliabilitas instrumen. Pengujian prasyarat analisis meliputi uji normalitas dan linearitas. Analisis data untuk uji hipotesis menggunakan analisis regresi linear sederhana dan untuk mengetahui besarnya kontribusi pengaruh variabel bebas terhadap variabel terikat digunakan koefisien determinasi. Hasil penelitian menunjukan bahwa ada pengaruh antara keaktifan dalam organisasi terhadap motivasi belajar matematika siswa SMA Negeri 1 Campalagian. Dengan kontribusi sebesar 15,4\% dan sisanya 84,6\% dipengaruhi oleh variabel lain.
\end{abstract}

Kata kunci : keaktifan dalam organisasi, motivasi belajar matematika

\section{PENDAHULUAN}

Mutu pendidikan dapat dilihat dari tingkat keberhasilan sekolah dengan tidak mengesampingkan peran masyarakat untuk menilai hal tersebut. Keberhasilan sekolah dapat dilihat pada hasil nilai Ujian Akhir Nasional yang dicapai siswa dalam mengikuti tes evaluasi tahap akhir. Bila nilai Ujian Akhir Nasional itu baik serta sebagian besar siswanya diterima di sekolah negeri pada jenjang sekolah yang lebih tinggi, maka sekolah itu dinilai sebagai sekolah yang berhasil. Selain itu, sekolah yang ditunjang dengan kegiatan-kegiatan menonjol seperti olahraga, kesenian, lomba mata pelajaran, kepramukaan dan sejenisnya yang sering mendapat prestasi, juga mendukung penilaian masyarakat akan keberhasilan tersebut. Di Sekolah juga terdapat berbagai kegiatan yang bersifat keorganisasian seperti Organisasi Intra sekolah (OSIS), Praja Muda Karana (Pramuka), Palang Merah Remaja (PMR), Pasukan Pengibar Bendera (PASKIBRA) juga ekstrakulikuler yang bersifat kebugaran jasmani seperti olahraga, basket, volly, futsal dan masih banyak lagi yang secara keseluruhan menuntut peran serta aktif siswa-siswi untuk terlibat didalamnya, tentunya diluar jam pelajaran yang telah ditentukan.

Kegiatan-kegiatan tersebut merupakan pelengkap dari kurikulum, yang dalam pelaksanaannya setiap siswa diberi keleluasaan untuk memilih kegiatan sesuai dengan minat dan bakatnya. Kegiatan Organisasi merupakan kegiatan yang dapat dijadikan sebagai wadah bagi siswa yang memiliki minat mengikuti kegiatan tersebut. Melalui bimbingan dan pelatihan guru, kegiatan organisasi dapat membentuk sikap positif 
terhadap kegiatan yang diikuti oleh para siswa. Kegiatan organisasi yang diikuti dan dilaksanakan oleh siswa baik di sekolah maupun di luar sekolah, bertujuan agar siswa dapat mengembangkan potensi, minat dan bakat. Pengertian organisasi menurut Kamus Besar Bahasa Indonesia yaitu, "organisasi adalah kesatuan (susunan dan sebagainya) yang terdiri atas bagian-bagian dalam perkumpulan dan sebagainya untuk tujuan tertentu. Kegiatan organisasi itu sendiri dilaksanakan diluar jam pelajaran wajib. Kegiatan tersebut harus dikelola dan diorganisir sebaik-baiknya oleh siswa di bawah pembinaan atau bimbingan guru agar tujuan-tujuan yang telah direncanakan dalam setiap jenis kegiatan dapat tercapai.

Menurut pendapat Amal dalam Cahyandaru (2013) kegiatan organisasi di sekolah ikut andil dalam menciptakan tingkat kecerdasan yang tinggi. Kegiatan ini bukan termasuk materi pelajaran yang terpisah dari materi pelajaran lainnya, dan dapat dilaksanakan di sela-sela penyampaian materi pelajaran, mengingat kegiatan tersebut merupakan bagian penting dari kurikulum sekolah. Namun, tak jarang juga dari beberapa siswa yang terlibat dalam suatu organisasi mengalami kesulitan mengatur waktu antara kepentingan akademik dan organisasi sehingga prestasi belajar menurun.

Seperti halnya yang terjadi di salah satu Sekolah Menengah Aatas yang ada di Kab. Polewali Mandar, menurut hasil wawancara yang dilakukan oleh peneliti kepada salah satu guru mata pelajaran di SMA Negeri 1 Campalagian yang bernama $\mathrm{Hj}$. Indrayani, S.Pd. yang mengungkapkan sebuah pendapat bahwa masalah yang sering dihadapi oleh siswa yang aktif dalam kegiatan organisasi adalah sebagai berikut, (1). Kurang pandainya siswa membagi waktu dengan baik untuk belajar, sehingga ada mata pelajaran tertentu yang tidak dituntas, (2). Siswa lebih cenderung mengutamakan kegiatan organisasi daripada belajar didalam kelas, (3). Beberapa siswa cenderung merasa malas dalam belajar dikarenakan kondisi fisik yang lelah, (4). Siswa menjadi sangat kritis dikelas meski untuk hal-hal yang tidak perlu dikeritisi dan (5). Siswa menjadi lebih sulit untuk diatur.

Selain dari pada keaktifan organisasi, pada prinsipnya ada dua faktor yang mempengaruhi keberhasilan siswa dalam mengikuti proses belajar mengajar, yaitu faktor intern dan faktor ekstern. Faktor intern yaitu faktor yang berasal dari dalam diri siswa itu sendiri, misalnya : motivasi, minat, intelegensi, sikap, cara belajar dan lain-lain. Sedangkan faktor ekstern adalah faktor yang berasal dari luar diri siswa, misalnya : keadaan sosial ekonomi, lingkungan sosial, sarana dan prasarana, guru, kurikulum dan sebagainya.

Salah satu faktor yang terpenting dalam pencapaian prestasi belajar adalah motivasi. Hal itu sesuai dengan apa yang dingkapkan oleh Syah dalam Fahlevie (2014) mengemukakan bahwa segala bentuk lingkungan sosial yang ada, memberi pengaruh terhadap aktifitas belajar siswa, salah satunya yaitu pergaulan dengan teman-teman sebaya kaitannya terhadap interaksi antar anggota organisasi.

Kegiatan organisasi merupakan salah satu faktor eksternal yang berhubungan dengan motivasi belajar. Sehingga keaktifan organisasi mempunyai kaitan erat dengan motivasi belajar. Slameto dalam Fahlevie (2014) mengemukakan kegiatan siswa dalam bermasyarakat dapat memberi dampak positif terhadap perkembangan kepribadiannya. Namun apabila siswa berpartisipasi pada bagian yang terlalu banyak seperti berorganisasi, keagamaan, kegiatan sosial dan lain sebagainya, maka belajarnya akan terganggu.

Keaktifan organisasi juga melibatkan orang lain sebagai teman kerja dalam berorganisasi dan juga teman dalam belajar serta bergaul. Slameto dalam Fahlevie (2014) menambahkan bahwa teman bergaul memberi pengaruh terhadap diri siswa, baik pengaruh positif maupun pengaruh negatif. Sehingga, berdasarkan teori-teori tersebut 
dapat disimpulkan bahwa bergaul dalam lingkungan organisasi juga memiliki pengaruh terhadap baik buruknya prestasi belajar yang siswa raih.

Berdasarkan pernyataan tersebut diatas, dapat diambil kesimpulan bahwa organisasi erat hubungannya dengan motivasi belajar siswa. Melalui kegiatan organisasi siswa dapat bertambah wawasan mengenai mata pelajaran yang erat kaitannya dengan pelajaran di ruang kelas dan biasanya yang membimbing siswa dalam mengikuti kegiatan organisasi adalah guru bidang studi yang bersangkutan. Melalui kegiatan organisasi juga dapat menyalurkan bakat, minat dan potensi yang dimiliki. Salah satu ciri kegiatan organisasi adalah keanekaragamannya, hampir semua minat remaja dapat digunakan sebagai bagian dari kegiatan organisasi. Hasil yang dicapai siswa setelah mengikuti organisasi dan berdampak pada motivasi belajar di ruang kelas yaitu pada mata pelajaran tertentu yang ada hubungannya dengan organisasi yaitu mendapat nilai baik pada pelajaran tersebut. Biasanya siswa yang aktif dalam kegiatan organisasi akan terampil dalam berorganisasi, mengelola, memecahkan masalah sesuai karakteristik organisasi yang digeluti. Berdasarkan kajian tersebut, peneliti tertarik untuk membahasnya dalam bentuk penelitian yang berjudul "Pengaruh Antara Keaktifan dalam Organisasi Terhadap Motivasi Belajar Matematika Siswa SMA Negeri 1 Campalagian Tahun Ajaran 2016 2017”.

\section{METODE PENELITIAN}

Penelitian ini menggunakan jenis penelitian ex post facto yang mengukur hubungan sebab-akibat keaktifan dalam organisasi terhadap motivasi belajar matematika siswa SMA Negeri 1 Campalagian tahun ajaran 2016/2017 pada saat yang bersamaan. Populasi dan sampel dalam penelitian ini adalah sama, yaitu siswa yang termasuk dalam keanggotaan OSIS SMA Negeri 1 Campalagian tahun ajaran 2016/2017. Dengan kata lain bahwa jenis sampling yang digunakan adalah sampling jenuh yaitu apabila sampel yang menjadi penelitian berjumlah kurang dari 30 maka anggota populasi tersebut diambil seluruhnya untuk dijadikan sampel penelitian.

Data yang digunakan dalam penelitian ini adalah data primer yang diperoleh dengan penyebaran instrumen penelitian berupa angket atau kuesioner kepada responden dengan maksud untuk mengumpulkan data tentang keaktifan dalam organisasi dan motivasi belajar matematika siswa SMA Negeri 1 Campalagian tahun ajaran 2016 - 2017. Instrument tersebut menggunakan skala likert yang memiliki jawaban dengan tingkat jawaban dari Selalu (SL), Sering (SR), Kadang-kadang (KD) dan tidak pernah (TP). Adapun aspek atau indikator yang dimuat dalam angket tersebut, dalam tabel berikut:

Tabel 1. Indikator instrumen keaktifan organisasi dan motivasi belajar matematika

\begin{tabular}{|c|c|}
\hline Variabel & Indikator \\
\hline Keaktifan dalam organisasi & $\begin{array}{l}\text { 1. Dorongan mengikuti kegiatan OSIS } \\
\text { 2. Kontribusi terhadap peningkatan OSIS } \\
\text { 3. Tingkat kehaditan } \\
\text { 4. Tujuan mengikuti kegiatan OSIS } \\
\text { 5. Kedudukan dalam OSIS }\end{array}$ \\
\hline Motivasi belajar Matematika & $\begin{array}{ll}\text { 1. } & \text { Tekun dalam menghadapi Tugas } \\
\text { 2. } & \text { Ulet dalam menghadapi kesulitan } \\
\text { 3. } & \text { Menujukkan minat belajar } \\
\text { 4. } & \text { Senang bekerja mandiri } \\
\text { 5. } & \text { Cepat bosan dengan tugas-tugas rutin } \\
\text { 6. } & \text { Tidak mudah melepaskan hal yang diyakini }\end{array}$ \\
\hline
\end{tabular}


Sebelum instrumen tersebut digunakan, terlebih dahulu dilakukan uji instrumen terkait validitas dan reliabilitas. Angket keaktifan dalam organisasi dan motivasi belajar matematika memiliki teknik validasi berupa: (a). Validasi Konstruk (contruct validaty), (b). Validasi Isi (content validaty) dan (c). Validasi Muka (face validaty). Instrumen penelitian dikonsultasikan secara langsung kepada tim validator ahli. Berdasarkan hasil uji validasi oleh tim validator pada aspek penilaian yang terdiri atas aspek petunjuk, aspek bahasa dan aspek isi, diperoleh nilai rata-rata sebesar 3,25. Nilai tersebut menunjukan bahwa instrumen/angket yang dibuat oleh peneliti dianggap valid.

Langkah selanjutnya adalah melakukan uji coba instrumen/angket secara empiris kepada sejumlah siswa yang dinyatakan setara dengan objek yang akan diteliti. Uji coba instrumen dilakukan di SMA Negeri 1 Labuan sebanyak 29 orang siswa dengan 36 item penyataan untuk variabel keaktifan dalam otrganisasi dan 30 dan 36 pernyataan untuk variabel motivasi belajar matematika siswa. Dari hasil analisis data keaktifan siswa dalam organisassi dengan menggunakan program aplikasi spss for windows, maka diperoleh 19 item pernyataan yang valid dan 11 diantaranya diyatakan tidak valid. Sedangkan hasil uji validasi data motivasi matematika siswa diperoleh item pernyataan yang valid sebanyak 29 item dan 7 diantaranya dinyatakan tidak valid. Berdasarkan hasil uji tersebut, diperoleh nilai Alpha sebesar 0.888, sehingga dapat disimpulkan bahwa nilai reliabilitas variabel keaktifan dalam organisasi termasuk sangat reliable. Serta nilai Alpha sebesar 0.949 menujukkan bahwa nilai reliabilitas variabel motivasi belajar matematika termasuk juga sangat reliable.

Untuk menjelaskan permasalahan penelitian ini, maka analisis data yang digunakan yaitu, (1) Analisis deskripsi, (2) Uji Prasyarat Analisis (Uji Normalitas dan Uji Linearitas), dan (3) Uji Hipotesis menggunakan Uji Regresi Linear sederhana.

\section{HASIL DAN PEMBAHASAN}

Adapun data hasil penelitian yang diperoleh setelah menyebarkan angket, diinterpretasikan sebagai berikut.

\subsection{Analisis Deskriptif}

Tabel 2 Interpretasi skor variabel keaktifan dalam organisasi

\begin{tabular}{|c|c|c|c|}
\hline Interval & Jumlah Siswa & Presentase & Kategori \\
\hline $0-20 \%$ & 0 & $0 \%$ & Sangat Lemah \\
\hline $21-40 \%$ & 0 & $0 \%$ & Lemah \\
\hline $41-60 \%$ & 0 & $0 \%$ & Cukup \\
\hline $60-80 \%$ & 15 & $51,72 \%$ & Aktif \\
\hline $81-100 \%$ & 14 & $48,28 \%$ & Sangat Aktif \\
\hline Total & 29 & $100 \%$ & \\
\hline
\end{tabular}

Sumber: Data primer yang diolah

Berdasarkan diagram tersebut, variable keaktifan dalam organisasi yang berkategori sangat aktif $51,72 \%$ dengan responden sebanyak 15 orang dan kategori aktif $48,28 \%$ dengan jumlah responden sebanyak 14 orang. Dengan demikian dapat disimpulakan bahwa keaktifan siswa SMA Neg 1 Campalagian dalam organisasi termasuk dalam kategori Aktif.

Tabel 3 Interpretasi skor untuk variable motivasi belajar matematika

\begin{tabular}{|c|c|c|c|}
\hline Interval & Jumlah Siswa & Presentase & Kategori \\
\hline $0-20 \%$ & 0 & $0 \%$ & Sangat Lemah \\
\hline
\end{tabular}




\begin{tabular}{|c|c|c|c|}
\hline $21-40 \%$ & 0 & $0 \%$ & Lemah \\
\hline $41-60 \%$ & 3 & $10,34 \%$ & Cukup \\
\hline $60-80 \%$ & 20 & $68,97 \%$ & Tinggi \\
\hline $81-100 \%$ & 6 & $20,69 \%$ & Sangat Tinggi \\
\hline Total & 29 & $100 \%$ & \\
\hline
\end{tabular}

Sumber: Data primer yang diolah

Berdasarkan diagram tersebut, variable motivasi belajar matematika yang berkategori sangat tinggi 20,69\% dengan responden sebanyak 6, katergori tinggi $68.97 \%$ dengan responden sebanyak 20 orang dan kategori cukup $10.34 \%$ dengan jumlah responden sebanyak 3 orang. Dengan demikian dapat disimpulakan bahwa Motivasi belajar siswa-siswi SMA Neg 1 Campalagian dalam pelajaran matematika termasuk dalam kategori tinggi.

\subsection{Uji Prasyarat}

a. Uji Normalitas Data

Dalam penelitian ini pengujian normalitas data menggunakan uji sampel Kolmogorov - Smirnov. Uji data ini data ini dilakukan dengan bantuan aplikasi spss for windows, dengan taraf signifikansi 5\%. diketahui bahwa nilai signifikansi sebesar 0,200 lebih besar dari 0,05, sehingga dapat disimpulkan bahwa data yang diuji Berdistribusi Normal.

b. Uji Linearitas

Uji linearitas dalam penelitian ini mengguanakan uji $\mathrm{F}$ pada taraf signifikansi $5 \%$. Berdasarkan hasil analisis pada tabel diatas dapat diketahui bahwa nilai $\mathrm{F}$ hitung = $1,415<\mathrm{F}$ tabel $=2,48$. Signifikan sebesar $0,276>0,05$, maka dapat disimpulkan bahwa antara keaktifan dalam organisasi dengan motivasi belajar matematika memiliki hubungan yang Linear.

\subsection{Uji Hipotesis}

Pengujian hipotesis dilakukan untuk mengetahui benar tidaknya hipotesis yang diajukan, karena pada dasarnya hipotesis adalah dugaan sementara yang sifatnya sementara. Pengujian hipotesis dalam penelitian ini menggunakan analisis korelasi product moment. Analisis tersebut digunakan untuk mengetahui koefisien korelasi antara variabel bebas (Keaktifan dalam organisasi) dan variabel terikat (motivasi belajar matematika). Adapun hipotesis yang diuji adalah sebagai berikut:

HO: Tidak Terdapat pengaruh yang signifikan antara keaktifan dalam organisasi terhadap motivasi belajar matematika siswa

H1 : Terdapat pengaruh yang signifikan antara keaktifan dalam osis terhadap motivasi belajar matematika siswa

Koefisien korelasi bertujuan untuk melihat seberapa besar pengaruh keaktifan dalam organisasi $(\mathrm{X})$ terhadap motivasi belajar matematika $(\mathrm{Y})$. berdasarkan hasil analisis yang telah dilakukan dengan menggunakan program aplikasi spss for windows, didapatkan koefisien korelasi antara X terhadap Y sebesar 0,393 nilai koefisien korelasi ini selanjutnya dikonsultasikan dengan tabel koefisien korelasi sebagai berikut :

Tabel 4. Hasil Analisis Data variabel X terhadap Y

\begin{tabular}{|c|c|c|c|c|c|}
\hline Variabe & \multicolumn{2}{|c|}{ Harga $\mathrm{r}$} & \multicolumn{2}{|c|}{ Signifikan } & \multirow{2}{*}{$\mathrm{r}^{2}$} \\
\cline { 2 - 4 } 1 & Hitun & Tabel & Hitun & $(\alpha)$ & \\
\hline
\end{tabular}




\begin{tabular}{|c|c|c|c|c|c|}
\hline & $\mathrm{g}$ & & $\mathrm{g}$ & & \\
\hline $\mathrm{X}-\mathrm{Y}$ & 0,393 & 0,367 & 0,035 & 0,05 & 0,154 \\
\hline
\end{tabular}

Sumber: data yang telah diolah

Berdasarkan tabel diatas, diketahui bahwa nilai $\mathrm{r}$ hitung lebih besar $\mathrm{r}$ tabel $(0,393>0,367)$ dan nilai signifikan lebih kecil dari $\alpha(0,035<0,05)$, maka dapat disimpulkan bahwa tolak $\mathrm{HO}$ dan terimah $\mathrm{H} 1$. Sehingga terdapat pengaruh yang signifikan antara keaktifan dalam osis terhadap motivasi belajar matematika siswa. Besarnya koefisien determinasi $\mathrm{r}^{2}=0,154$ yang berarti bahwa variabel $\mathrm{x}$ memberikan pengaruh sebesar $15,4 \%$ dan sisanya $84,6 \%$ dipengaruhi oleh variabel lain.

Hasil analisis dengan menggunakan program aplikasi spps for windows didapat nilai constannya (a) sebesar 34,144 sedangkan koefisien garis regresinya (b) adalah sebesar 0,836 . dengan demikian persamaan regresinya dapat dituliskan sebagai berikut:

$$
Y^{\prime}=34,144+0,836 X
$$

Dari persamaan regresi tersebut dapat diartikan bahwa, bila nilai $\mathrm{X}$ atau penerapan keaktifan siswa dalam kegiatan organisasi bertambah, maka prestasi belajar siswa bertambah sebesar 0,836 dan bila nilai $\mathrm{X}$ atau penerapan keaktifan siswa dalam kegiatan organisasi tidak ada kenaikan nilai, maka nilai $\mathrm{Y}$ atau prestasi belajar adalah 34,144. Pernyataan di atas menjelaskan bahwa koefisien garis regresi tersebut positif, maka dapat disimpulkan bahwa pengaruh keaktifan siswa dalam kegiatan organisasi memiliki pengaruh positif terhadap motivasi belajar matematika siswa SMA Negeri 1 Campalagian. Artinya semakin aktif mengikuti kegiatan organisasi semakin baik pula motivasi belajar matematika siswa.

Selanjutnya, berdasarkan data hasil penelitian tersbut di atas, maka diperoleh rincian hasil penelitian sebagai berikut:

\section{Keaktifan Siswa Dalam Organisasi}

Hasil penelitian menunjukan bahwa keaktifan siswa dalam organisasi termasuk dalam kategori Aktif, yaitu sebesar 51,72\%. Hal ini disebabkan karena adanya banyak faktor yang mendukung pelaksanaan kegiatan organisasi osis di SMA Neg. 1 Campalagian, sehingga pelaksanaan kegiatan organisasi berjalan dengan baik dan siswa semakin tertarik untuk aktif mengikuti kegiatan organisasi OSIS. Adapun faktor-faktor pendukung pelaksanaan kegiatan organisasi tersebut diantaranya, (1).Tersedianya sarana dan prasarana yang memadai, (2).Adanya semangat pada diri siswa, (3). Adanya komitmen dari kepala sekolah, guru dan murid itu sendiri, (4). Adanya tanggung jawab.

Dengan demikian keaktifan siswa dalam organisasi pemberikan pengalaman belajar yang memiliki nilai manfaat bagi pembentukan pribadi siswa yang sesuai dengan keadaan, minat, keinginan, potensi dan kebutuhan siswa masing-masing sehingga keterlibatannya atau keaktifan siswa dalam organisasi dapat member pengaruh yang positif.

\section{Motivasi Belajar Matematika}

Hasil penelitian menunjukan bahwa keaktifan siswa dalam organisasi termasuk dalam kategori Tinggi, yaitu sebesar $68.97 \%$. hal ini disebabkan karena minat dan keinginan serta rasa keingintahuan siswa akan sesuatu sehingga mendorongnya untuk bergerak dan melakukan sesuatu sesuai dengan tujuan ingin dicapainya.. 
Dengan demikian, motivasi adalah sesuatu yang bersumber dari diri seseorang individu yang mendorongnya untuk melakukan sesuatu sesuai dengan kehendaknya dengan tujuan untuk mencapai sesuatu yang dikehendaki.

3. Keaktifan Siswa Dalam Organisasi Terhadap Motivasi Belajar Matematika Siswa SMA Negeri 1 Campalagian

Hasil penelitian menyatakan bahwa terdapat pengaruh yang signifikan antara keaktifan dalam organisasi terhadap motivasi belajar matematika SMA Negeri 1 Campalagian Tahun ajaran 2016/2017. Hasil analiasi diperoleh nilai signifikan 0,035 < taraf signifikan $\alpha 0,05$. Sedangkan nilai $\mathrm{r}^{2}=0,154$, hal ini menunjukan adanya pengaruh yang positif dan signifikan antara keaktifan dalam organisasi terhadap motivasi belajar matematika siswa SMA Negeri 1 Campalagian tahun ajaran 2016/2017. Pengaruh keaktifan dalam organisasi terhadap motivasi belajar matematika siswa sebesar $15,4 \%$ dan sisanya $84,6 \%$ dipengaruhi oleh variabel lain yang tidak dibahas dalam penelitian ini.

Dengan demikian siswa yang aktif dalam organisasi akan dapaat mengambil nilai-nilai positif dari kegiatan yang diikutinya sehingga dapaat mencapai motivasi belajar matematika sesuai dengan yang diharapkan.

\section{KESIMPULAN}

Dari keseluruhan uraian dalam skripsi ini maka diambil kesimpulan yang merupakan gambaran menyeluruh dari hasil pembahasan, yang dapat dikemukakan sebagai berikut :

1. Variabel keaktifan dalam organisasi yang berkategori sangat aktif $51,72 \%$ dengan responden sebanyak 15 orang dan kategori aktif 48,28\% dengan jumlah responden sebanyak 14 orang. Dengan demikian dapat disimpulakan bahwa keaktifan siswa SMA Neg 1 Campalagian dalam organisasi termasuk dalam kategori Aktif.

2. Variabel motivasi belajar matematika yang berkategori sangat tinggi $20,69 \%$ dengan responden sebanyak 6,katergori tinggi $68.97 \%$ dengan responden sebanyak 20 orang dan kategori cukup $10.34 \%$ dengan jumlah responden sebanyak 3 orang. Dengan demikian dapat disimpulakan bahwa Motivasi belajar siswa-siswi SMA Neg 1 Campalagian dalam pelajaran matematika termasuk dalam kategori tinggi.

3. Terdapat pengaruh yang signifikan antara keaktifan dalam organisasi terhadap motivasi belajar matematika SMA Negeri 1 Campalagian Tahun ajaran 2016/2017. Hasil analiasi diperoleh niali signifikan $0,035<$ taraf signifikan $\alpha 0,05$. Sedangkan nilai $\mathrm{r}^{2}=0,154$, hal ini menunjukan adanya pengaruh yang positif dan signifikan antara keaktifan dalam organisasi terhadap motivasi belajar matematika siswa SMA Negeri 1 Campalagian tahun ajaran 2016/2017. Pengaruh keaktifan dalam organisasi terhadap motivasi belajar matematika siswa sebesar 15,4\% dan sisanya84,6\% dipengaruhi oleh variabel lain.

\section{DAFTAR PUSTAKA}

Cahyandaru, Handoko. 2013. Pengaruh Keaktifan Siswa dalam Ekstrakulikuler terhadap Prestasi Belajar Siswa Kelas XI MAN Yogyakarta II. Skripsi. Yogyakarta: Unversitas Negeri Yogyakarta

Fahlevie, Rezza, Iqbal. 2014. Pengaruh Aktivitas Organisasi Mahasiswa terhadap Motivasi Belajar di Fakultas Agama Islam Iniversitas Muhammadiyah Yogyakarta. Skripsi. Yogyakarta: Universitas Muhammadiyah Yogyakarta 
Iskandar, Resya. 2016. Pengaruh Keaktifan Berorganisasi Siswa di Sekolah terhadap Motivasi Belajar Siswa Kelas X Dan XI SMA Negeri 1 Kartasura Tahun Ajaran 2015/2016. Surakrta: Universitas Muhammadiyah Surakarta

Mappeasse , Muh. Yusuf. 2009. Pengaruh Cara dan Motivasi Belajar Terhadap Hasil Belajar Programmable Logic Controller (PLC) Siswa Kelas III Jurusan Listrik Smk Negeri 5 Makassar. Jurnal MEDTEK. Volume 1, Nomor 2. Oktober 2009.

Rahman, Ade. 2013. Pengaruh Partisipasi Siswa dalam Organisasi Ekstrakurikuler terhadap Motivasi Belajar Siswa Kelas XI SMK Karnas Sindangwangi Majalengka. Cirebon: Institut Agama Islam Negeri ( IAIN ) Syekh Nurjati 